Article

\title{
What Happened to Andres Lapeteus? An Upper-Class Homo Sovieticus Caught in the Gears of Soviet Modernity
}




\section{ABSTRACT}

This article looks at What Happened to Andres Lapeteus? (Mis juhtus Andres Lapeteusega, Estonia, 1966), a film that marked the directing debut of Russian-Estonian theatre and film director Grigori Kromanov, as a cinematographic narrative that follows the development of a homo sovieticus. The concept of homo sovieticus, initially simply an ironic reference to the "New Soviet Man" promoted in the official Soviet vocabulary, was elaborated in the 1980s and 1990s by several thinkers and writers from Eastern Europe into a concept allowing for a more analytical description of the bureaucratic human type that developed under the Soviet regime. The GermanAmerican philosopher Hannah Arendt in her renowned The Origins of Totalitarianism (1951) found that the juridical, the moral, and the individual in a man could most effectively be killed in concentration camps. The Russian philosopher Aleksandr Zinoviev and the Polish philosopher Józef 'Tischner, however, have seen the homo sovieticus syndrome as resulting from spiritual rather than physical imprisonment. Predisposed by the planned Soviet economy, which did not motivate Soviet people to make any creative, intellectual, or moral efforts, homo sovieticus soon started to represent a certain official ritualistic behaviour that maintained the symbolic legitimacy of power. What Happened to Andres Lapeteus? tells the story of an ambitious young Estonian official during Stalinist and post-Stalinist years, but does it in a novel way for its time, tackling the popular criticism of the cult of personality in the Thaw era from the viewpoint of individual responsibility. Offering a charismatic black-and-white version of the novel The Case of Andres Lapeteus (Andres Lapeteuse juhtum, 1963) by the Estonian writer Paul Kuusberg, Kromanov's new wave film still makes us ponder the often avoided and delicate issue of the Sovietisation of the Baltic states from the inside. 
The 1966 feature film What Happened to Andres Lapeteus? (Mis juhtus Andres Lapeteusega?, Estonia) marks the RussianEstonian theatre and film director Grigori Kromanov's film directing debut and is based on The Case of Andres Lapeteus (Andres Lapeteuse juhtum), a 1963 novel by the Estonian writer Paul Kuusberg. Kromanov, whose status as the local cult director standing behind the most beloved Soviet Estonian films, such as The Last Relic (Viimne reliikvia, 1969) and The Dead Mountaineer's Hotel (Hukkunud alpinisti hotell, 1979) was still ahead, must have been looking for a contemporary plot for his first film or been personally enthralled by the story of Andres Lapeteus. The screenplay was commissioned from Kuusberg long before the book had received a Soviet Estonian literary prize and its Russian translation was distributed throughout the Soviet Union in 1965. In fact, immediately after its publication, several Estonian TV, theatre, and film directors had shown interest in this novel with a distinctively sharp social edge. And in subsequent discussions related to the film, regrets were expressed about some of the delays that occurred in the film sector because the translation of the book was not immediately approved by certain editorial circles in Moscow. Despite this, the first version of the screenplay was completed already in the autumn of 1964 and approved by the Tallinnfilm Art Council on the condition that some corrections are made. The second, amended version of the screenplay was reviewed by the Main Directorate of Cinematography in December of the same year and again approved on the condition that some corrections are made. The third version was finally approved for production on 29 April 1965. ${ }^{2}$ From there on, everything progressed smoothly. The film was assigned the highest category at Tallinnfilm and premiered in March 1966 at the Kosmos widescreen cinema, the most modern cinema in the Baltic republics which had been completed two years earlier. In Moscow,

ERA, f R-1707, n 1, s 963, l 15. ERA, f R-1707, n 1, s 963, I 1. the film was shown for the first time in June 1967, and in the same year, it was honoured with a special prize at the film festival of the Baltic, Belarusian, and Moldovan Soviet Republics for successfully examining an important social issue. The local critics had nothing but praise for the film, and it was especially acclaimed for its innovative and successful artistic approach. However, isn't this success story surprising considering the fact that, despite some censoring of the original screenplay, the final filmed version focused on an ambivalent hero, whose downfall could be attributed to the Soviet system?

Below, I will examine What Happened to Andres Lapeteus? as a cinematic narrative that observes the development of homo sovieticus, a concept derived from Soviet dissident language usage, which has been elaborated by several thinkers and writers from Eastern Europe, especially from Russia and Poland, since the 1980s. Because, perhaps is there no other portrait of homo sovieticus that is as perceptive or possesses a greater power of generalisation to be found among the cultural texts written in Estonia during the late Soviet period? Endel Nirk, one of Estonia's most authoritative literary scholars and critics from the 1960s, has described The Case of Andres Lapeteus as a Bildungsroman that examines the development of one character, but which is so closely connected to the specificities of social life in that era that it "becomes a social generalisation with a broad foundation, an examination of the complicated and contradictory conditions of this time period" (Nirk 1963: 706). Kromanov's charismatic black-and-white film version only enhanced the strengths of the novel. Eva Näripea, a researcher of Eastern European cinema, has said that Kuusberg's journalistic style was transferred to film without anything being lost and the visually fresh formulation even increased its power (Näripea 2006: 56). In retrospect, the 1960s has mostly been viewed in two ways in Estonian cultural history. On the one hand, it is seen as an optimistic decade, which was called golden at the time, when the promising 
Thaw was still underway throughout the Soviet Union. And on the other hand, it is the decade when the first Soviet generation that lacked any personal memories of free Estonia or cautionary experiences of Stalinist repressions entered the social arena. Estonian literary critic and essayist Andres Langemets has characterised the mentality of the sixties generation as follows: "The understandings and insights of my generation developed mostly with the help of individual representatives of the older generation, who dared to start being honest with us. Some of us learned from this and some did not. There were many people who were well aware of the truth, but who, calmly and with a very clear head still started pursuing Communist careers. When having a shot of vodka they would sigh and curse, but in the morning they would still go to their offices to cower and complain about us to others. And when we met on the street, they would suddenly want to shake our hands, according to the Russian custom." (Langemets 2010) Although the Sovietisation of the Baltics from the outside has started to be researched with sufficient thoroughness (Zubkova 2009), the same cannot be said about the Sovietisation of the Soviet Republics from the inside. And maybe it is best to raise this delicate issue in the context of a successful artistic representation, which What Happened to Andres Lapeteus? undoubtedly is.

In 1981, the Russian philosopher, sociologist, and dissident writer Aleksandr Zinoviev, then already in exile, publishes a satirical novel called Homo Sovieticus, which, in a grotesque-humorous idiom, provides a first-person account of the average Soviet person, a bureaucratic human type that has been cleansed of any individuality, and whose main aspiration in life is to ideally blend into the collective, to be perfectly conformist. Of course, homo sovieticus, a pseudo-Latin neologism with characteristic dissident irony, alludes to the "New Soviet Man" promoted in the official Soviet vocabulary, giving it a sarcastic assessment and emphasising the gap that existed between the ideological Soviet slogans and the cynical Soviet reality. Popular encyclopaedias have described the main traits of homo sovieticus as the following: a lack of initiative and personal responsibility; an indifference toward the preservation of the common property belonging to the state; the habit of petty thievery; as well as the idealisation of everything Western and viewing it as exotic; the passive submission to the government's decisions; and often a tendency to drink too much (http://en.wikipedia.org/wiki/Homo_ Sovieticus). Of course, for Zinoviev, who has described homo sovieticus in several of his satirical works, the latter is a symbol, a universal human type, or set of human traits, which can most probably also be found outside of the Soviet Union and the post-socialist arena. However, as a mass phenomenon, this human type became a feature of the 20th-century totalitarian regimes, the comparison of which was a new, eyeopening experience for many in the Western world during the post-war years. In the 1950s, Hannah Arendt, one of the most influential political philosophers of the past century, was one of the first to juxtapose the totalitarian regimes of Europe and to recognise that their functioning and survival was ensured not only by an all-powerful centralised power, but also by the bureaucratic masses that had been cleansed of individuality. According to Arendt, total domination, which neutralises plurality and differences, can only be achieved if the juridical, the moral and the individual person is killed in a man and the human being can be returned to its natural primeval state of preserving the species (Arendt [1951] 1973: 438-453).

Arendt believed that the development of such a human type in its purest form is possible only in concentration camps. However, several East European thinkers with socialist experiences have found that homo sovieticus syndrome occurs as the result of spiritual rather than physical imprisonment. In 1992, Józef Tischner, a Polish Catholic priest and philosopher, the chaplain of the Solidarity trade union, and one of the moral authorities of the Polish transition period, published The Ethics of Solidarity 
and Homo Sovieticus (Etyka solidarności oraz Homo sovieticus), a book in which he describes homo sovieticus as a post-socialist, rather than socialist condition of fleeing from freedom (Tischner 2005: 141). According to Tischner, homo sovieticus is not a communist but a client of communism, who, in the next moment, could as well be a client of capitalism. However, Tischner thinks that a central role in the development of homo sovieticus was played by the planned Soviet economy (Tischner 2005: 142), which did not motivate Soviet people make any creative, intellectual, or moral efforts and made the fruits of their labour and personal contribution meaningless, because they disappeared into the black hole of the great future-oriented project (Tyszka 2009: 510). Therefore at a time when the compensation that one received in the capitalist system was directly related to the results of one's labour, homo sovieticus, who worked under the conditions of a planned economy, did not develop a work ethic, because work did not have any meaning for him or her. In the semiotic sense, work was a signifier without the signified, and therefore, the motivation to make an effort rapidly disappeared. Zinoviev's first-person homo sovieticus summarises his worldview as follows: "I often have a wish to get something done; but I very rarely have the wish actually to do what I want to get done." (Zinoviev 1985: 9) Many Polish sociologists who have examined the homo sovieticus syndrome believe that it is an adaptive transitional type, which appears in late socialism and represents certain official ritualistic behaviour that maintains the symbolic legitimacy of power (Marody 2010: 82). In the Soviet Union it is more difficult to speak about homo sovieticus during the Stalinist era, which was ruled by an atmosphere of fear, when every family had either a direct or indirect contact with repression, and therefore, the official rituals were fulfilled to protect oneself or one's intimates in reality. Thus, it seems somewhat safer to start the examination of this phenomenon from the Thaw period, when arbitrary Stalinist terror disappeared, but the inert Stalinist mentality did not disappear as easily.
What Happened to Andres Lapeteus? is set in post-World War II Estonia, starting with the Stalinist 1940s and ending with the Thaw in the early 1960s. Just like the book, the film is structured as a collage of various moments in time, and a complete picture for the viewer is not created until the very end of the film. Thus, with its collage-like structure and with its question-formed title that appears on a broken car window in the very beginning, the film observes the logic of the detective genre. The first scene shows the traffic accident caused by Andres Lapeteus that results in his friend's death and, thereafter, the film starts investigating the clues, intermittently cutting back to the scene of the accident, and letting the viewer seemingly participate in the solution of a crime. The title of Kuusberg's book, The Case of Andres Lapeteus, alludes more directly to crime fiction, although the novel only plays with the formal clichés of the Western detective genre, as in the Soviet Union, there was no official place for this genre that revolved mainly around ownership. However, this is hardly a typical criminal case, because an unequivocal answer to the question of what happened to Andres Lapeteus or whether Lapeteus is guilty of anything is not and cannot be provided by the film with its open-ended conclusion. Moreover, the accusation against Lapeteus is broader, more universal, and actually exceeds the competence of the courtroom. Still, we can find some conceptual affinity with the trial of the high-ranking Nazi officer Adolf Eichmann, organiser of the mass deportation of Jews, in Jerusalem in 1961, which was covered in The New York Times by Arendt and also widely discussed in the Soviet media (Cantorovich 2007). At that time, under-16-year-olds were not allowed to see What Happened to Andres Lapeteus? and from today's viewpoint, this was justified not so much because of the sexual scenes in film, but because it deals with complicated ethical problems in a fairly ambivalent way. It requires the viewers to actively think independently and does not provide young people with any clear guidelines for life. The literary scholar Jaan 
Undusk has said the main innovation in the film is Ada Lundver's role of the sensuous blonde who disintegrates the trivial system of the Soviet working man and is filmed lying about from different angles (Lõhmus, Vaher 2012). The film critic Jaan Ruus has found that the most novel aspects of the film within the framework of the times are the open-ended conclusion of the film and the title ending with a large question mark (Lõhmus, Vaher 2012), which was generally unacceptable in the didactical and unambiguously comprehensible canon of Soviet art.

For the role of Andres Lapeteus, the Tallinfilm Art Council could not decide between two popular male actors - Einari Koppel and Jaan Saul. Finally, Koppel was chosen, who, according to the council was more natural and had already played Lapeteus on stage at the Vanemuine Theatre. ${ }^{3}$ To prepare for her casting as Reet Lapeteus, Kromanov suggested to his favourite Ada Lundver, that she go to the zoo, observe the tigers and leopards, and present a study of impudence at their next meeting (Lõhmus, Vaher 2012). Lundver got the role and, in a way, with her shameless sensuous performance she contributed to the Soviet sexual revolution. Both Kaljo Kiisk and Jüri Järvet were considered for the role of the film's high-minded and truth-speaking worker Pajuviidik, but Kiisk got the role as the fresher screen face. ${ }^{4}$ The other high-minded role went to Ita Ever - the female comrade Helvi Kaartna, Lapeteus's wartime sweetheart, who remains true to her inner moral compass until the end of the film, and subsequently marries Oskar Põdrus, the ideological communist who is expelled from the Communist Party. Põdrus, the persecuted communist and intellectual, was played by Heino Mandri, an actor who had been imprisoned for seven years for not reporting the existence of an anti-Soviet organisation, and who remained in the KGB's sphere of interest even after he returned from prison camp. The actor's case was not reviewed until the perestroika era and Mandri was officially rehabilitated right before his death in 1990 (Koppel 1998). Rein Aren, a beloved actor at the time, played Viktor Haavik, the man with the most buoyant morals and the one who was most skilful at swimming with the times. Haavik pursues a successful career and wins over Lapeteus's wife, but finally dies in quite a silly way as the result of a traffic accident. If the Tallinnfilm Art Council envisioned Haavik's character as a slippery one, then Madis Jürven, the dogmatic party member, was supposed to seem hard-hearted. ${ }^{5}$ Raffail Beltšikov, the chairman of the Film Committee, who was appointed to defend ideological purity in the Art Council, tried to oppose the portrayal of Jürven as hard-hearted, by suggesting that the character be one "who is sure in his heart of what he expresses in his words and who tries to manage the work entrusted to him". ${ }^{6}$ However, the role was given to Ants Eskola, who, as an actor who had already been active at the Estonia Theatre before the war and later personally experienced Stalinist repressions, played Jürven with a characteristic restraint that made him hard-hearted still.

We see all the film's main characters in the scene where the comrades-in-arms are on a train returning from the battle at Velikije Luki. (Figure 1) They are making plans, poking fun at each other, dreaming about their future lives, talking about friendship, their calling in life and careerism - about what they want to become, and what is important in civilian life. This first scene is symbolic, because it establishes the main theme of the film - the self-discovery of a group of people who have survived the war and are now facing new, initially Stalinist and thereafter post-Stalinist, conditions. It quickly becomes clear that Andres Lapeteus's promise is what the viewers should remember from this scene - his promise that those who become friends during wartime should remain friends throughout their lives. The latter is also confirmed by the lyrics of the song heard during the scene- 
"Let's smoke a cigarette, boys, [in the mouth of the oven, and let's keep together]". It is played on guitar several times during the film as a reference to this first scene and the promise that was made there. However, from hereon, the film focuses on Andres Lapeteus, a young ambitious official, whose post-war life, career, and inner development is closely monitored. Undusk has considered the book-Lapeteus to be a positive character, right from the start, whereas the film-Lapeteus he deems as suspicious, ambivalent character (Lõhmus, Vaher 2012). The film-Lapeteus is irresolute; his values are shaky; he often hesitates and avoids taking a position on important questions. He consistently makes pragmatic careeroriented choices, but later seems to long for the permanent values of life, like friendship and love, convictions, a clean conscience, and peace of mind. In his book of the same name, Zinoviev has his homo sovieticus say, "[w] hat I'm saying here doesn't express my convictions. And, what is more, it's only an apparent mystery: I haven't got any convictions. I've only got a more or less stable reaction to everything I bump up against: a behavioural stereotype. [---] If a man has convictions it is a sign that he is not intellectually mature." (Zinoviev 1985: 11) If we compare this statement to the friends in the film, Põdrus, who is thrown out of the Communist Party has convictions and they do not allow him to compromise. Whereas, as time goes on, Lapeteus, who has remained a party member, is left with official slogans. In the novel, this is revealed by Lapeteus's stream of conscience while speaking about the purpose of life with his friends in a restaurant: "Andres Lapeteus again thought how he would be in a bind if he had to clearly state what he was striving for, what his life purpose was. Of course, he could talk about socialism and people's happiness, but anyone who accepted the Soviet order could talk about that." (Kuusberg 1966: 103) In the film, the contrast between this inner dialogue and the conversation, which is typical of the homo sovieticus, is not apparent, since the stream of conscience that expresses the richness of the character's inner world had been left out and the film focuses on the dialogue.

According to Zinoviev, homo sovieticus is typified by behaviour that changes depending on whether he is in a group or outside a group. Thus, it is quite usual for a homo sovieticus to applaud the decisions of the party when among, while condemning the same decisions when he is outside that group. This is because in the former case, the assessment is abstract, but in the latter, it is concrete (Зиновьев 1981: 41). The Polish sociologist Krzysztof Tyszka speaks about a kind of dimorphism of values in homo sovieticus whereby differing behavioural patterns develop depending on the context. In one context, the private one for example, one reasoning, or even ethical thinking, may apply, and in another context, the public one for example, totally different reasoning may apply; because for homo sovieticus a different axiology may exist for each context (Tyszka 2009: 513). Just such a dimorphism of values appears in Andres Lapeteus - he is one person when he is with his friends, and another at the ministry. And this is especially apparent when these two spheres accidentally collide - when Lapeteus meets a friend at the ministry or at work, he seems to be confused and does not know what to say, how to behave. In the long term, this dimorphism of values in homo sovieticus can develop into ethical relativism and cynicism, which may also cause suffering for the carrier - but not necessarily. According to Zinoviev, a genuine homo sovieticus is a Soviet agent, who does not see anything good or bad in this. It is simply a banal objective fact, maybe a sad fact, maybe a comical fact, but definitely not a tragic one (Зиновьев 1981: 47). Yet, unlike his best friend Haavik, Lapeteus is torn between the different contexts, and does not really belong to either. Therefore, he complains to his friends that he sometimes feels extremely alone, but his friends do not harbour any ill feelings toward him nor do they feel any special friendship.

For the upper class homo sovieticus, the dimorphism of values applies to much broader areas because the reality of life in 


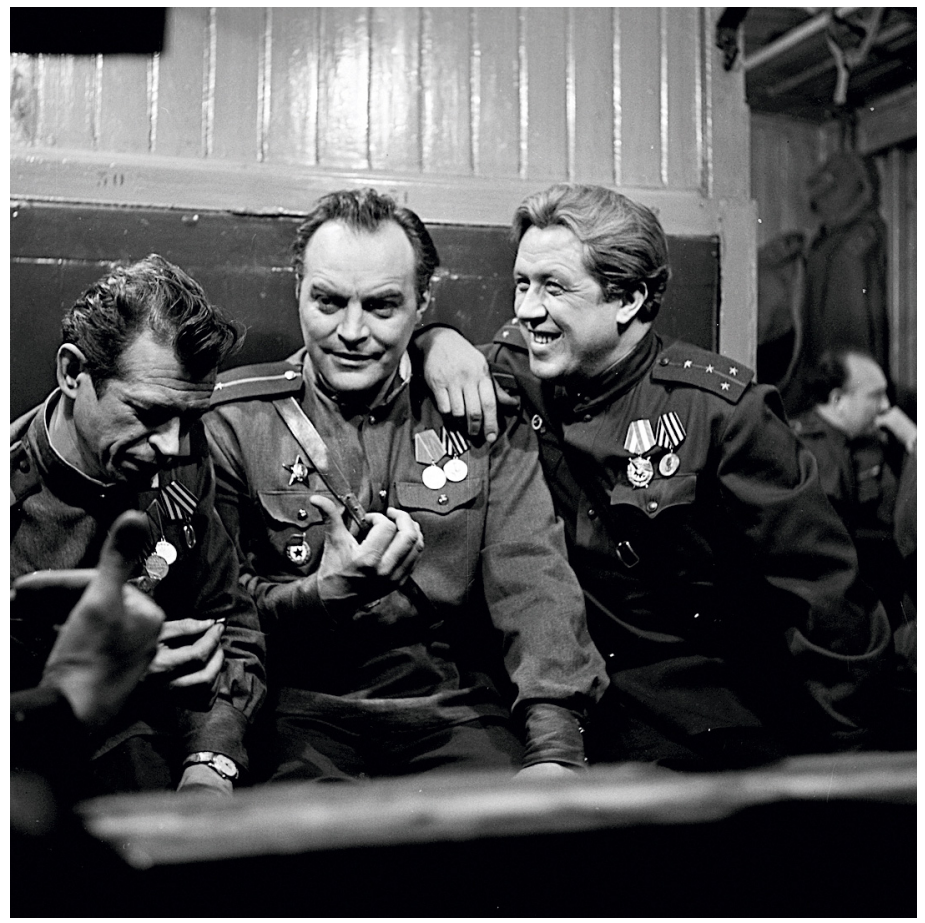

FIGURE 1. Comrades-in-arms on a train merrily returning from the battle at Velikije Luki: Pajuviidik, Haavik, and Lapeteus. Photo: Tallinnfilm / Film Archives of the National Archives of Estonia.

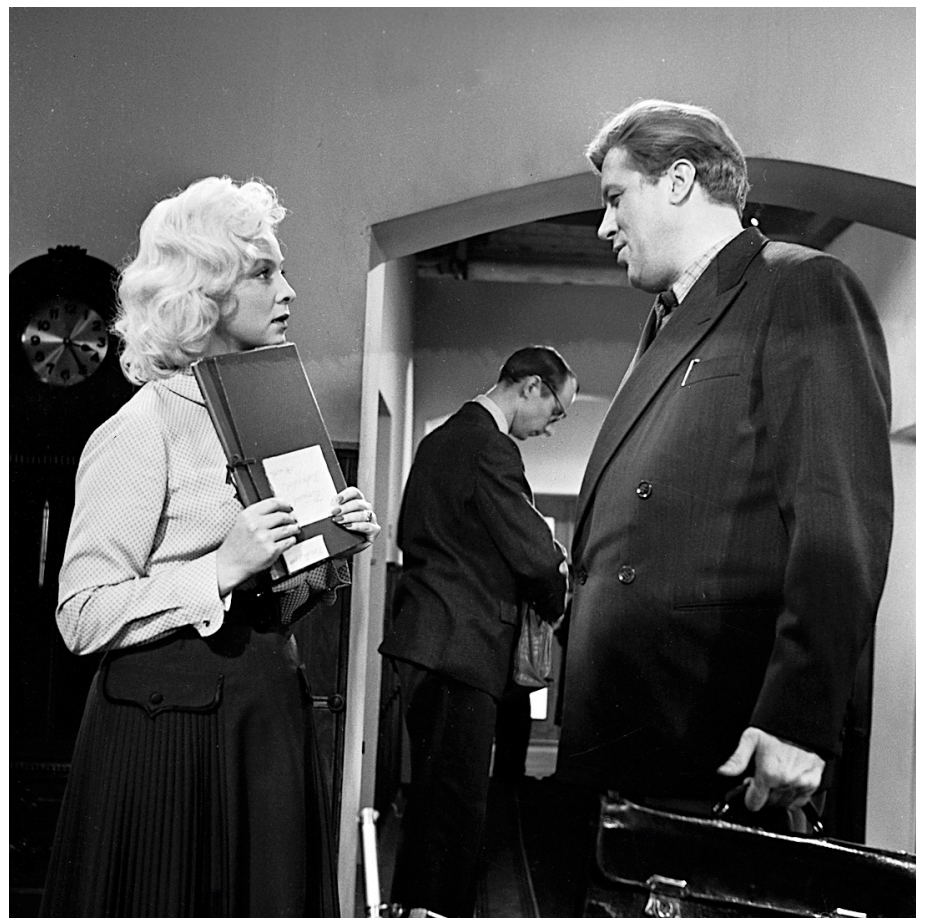

FIGURE 2. The relationship of Reet and Andres Lapeteus starts out as workplace romance. Photo: Tallinnfilm / Film Archives of the National Archives of Estonia. 
the Soviet nomenklatura did not differ much from the life of the upper middle class in the West. Consumption, position, and benefits were important, along with the social and sexual capital that accompanied the power and benefits, although officially all the latter were soundly condemned. In Lapeteus's life we can clearly see how his social and sexual capital increases as he rises up the career ladder. The sensuous blonde Reet develops an interest in Lapeteus when he becomes a high official in the forestry ministry, and it culminates when he becomes the vice-chairman of the oblast's executive committee. (Figure 2) This interest starts to slowly wane when he becomes the director of a factory and his status as an upper class homo sovieticus starts to degenerate. However, both are calculating rationalists. If Reet is interested in a man with minister potential, then Andres subconsciously senses that his sexual capital has a time fuse and that the sensuous blonde Reet is only available to him here and now. Reet plays an important role in the development of Lapeteus as the main character, because, as a clever woman, she uses her erotic power over the man to try and inspire him. A good example is the scene where Reet rebuffs his morning hug, saying "not until we have a personal car". Later, when they are already married, Andres brings a new Volga into the family thereby again temporarily resolving a problem in their relationship. For Lapeteus, Reet's ability to orientate in the nomenklatura system and spur him on as a leader is exciting right from the start. Lapeteus mostly responds with passionate kisses to the woman's playful remarks, in which she addresses him using the formal You that alludes to an official relationship: "You a are such a big boss now, but You are not happy at all." Reet, on the other hand, is charmed by Andres's ambition, his unflagging power and energy, and the man's ability to simultaneously work and study earns almost a Stalinist compliment from the woman: "You are an iron man, one that could move mountains." Ada Lundver splendidly portrays the two-faced role of a Soviet woman of the 1960s - to be clearly modern and self-aware at one moment, a sensual temptress, and play decent and sexually inexperienced at the next. In the public Soviet sphere, the attitude toward sexuality was quite infantile right up to the end. This is symbolised by probably the most erotic scene in the Estonian cinema of the 1960s, which ends quickly with the lights being turned off.

Reet's wish is that her man exceed the requirements of the era, and the more Lapetus's status as an upper class homo sovieticus degenerates, the more Reet becomes interested in Viktor Haavik, who is a homo sovieticus that is on a smooth career path and does not take life too seriously. (Figure 3) Her husband's seriousness and work-centred attitude irritates Reet Lapeteus, because a true homo sovieticus is not a stupid workhorse but a clever delegator and skilful opportunist. According to Zinoviev, homo sovieticus is a resilient and agile operator who is able to adapt quickly to different circumstances and flexibly grasp the opportunities that life presents (Зиновьев 1983: 75). Haavik is better at this than Lapeteus and, as the film progresses, we see the inexorable degeneration of Lapeteus in the conjectural social plane, which he cannot, and perhaps does not, want to prevent, because his increased apathy and inner emptiness has done their job. Lapeteus again loses his self-control in the car scene, when he lashes out at Reet saying, "I'm sick of your speculator and kulak friends. Have you found your minister now?" To which Reet replies as if stung, "You're so low!" But in a way, Reet is right, because in the context of the Soviet nomenklatura with its double standard of morality, Lapeteus behaves like a lout, like someone who does not grasp the nuances of the ruling culture, does not really know how to behave. Czesław Miłosz has described the fine art of role playing that developed in Soviet times as a form of katman, the Middle Eastern art of hiding one's thoughts and feelings. The people practicing this art assess their ability by misleading or outsmarting their opponents - who in turn try to do the same. And since the constant 


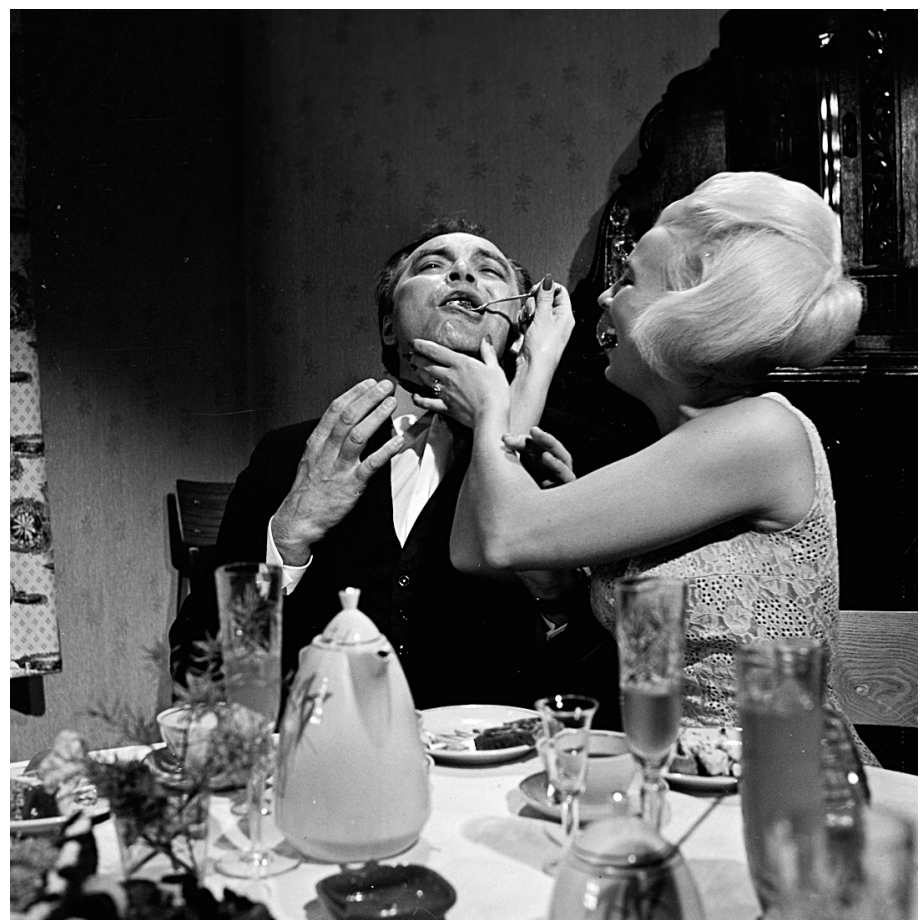

FIGURE 3. Reet Lapeteus flirting with Haavik, a man on a smooth career path that does not take life too seriously. Photo: Tallinnfilm / Film Archives of the National Archives of Estonia. 
concealment creates an oppressive atmosphere, the main source of pleasure in katman is the game itself (Miłosz 1999: 52).

Before the fatal collision, Lapeteus sees his friend Haavik's face, but does not see, or forgets due to his injury, that his wife is sitting in the car beside his friend. Reet Lapeteus, having lost a lover with career potential in the accident and been left with a crippled, and in the social sense bankrupted, husband, asks hopelessly, "Is the high point of my life over? Will they throw him out of the party?" However, Reet cannot be seen as a homo sovieticus, because she uses the systems in order to outsmart them and take advantage of them to enjoy life. She has no plans to start serving them or to take them serious even as external rituals. On the morning when Reet and Andres are talking about their wedding and Andres says that as a communist he cannot wear a tailcoat or tuxedo to his own wedding, Reet summarises her understanding of socialism as follows: "I have always argued against those who say that bolshevism means a mass person".

If Andres Lapeteus brings a high social position to the marriage, then Reet Lapeteus brings a private residence along with a hedonist lifestyle and amusing bourgeois friends. The film includes several party scenes filmed with a Fellini-like camera eye, which, with their abundant food, bawdy songs, chain dances, worldly vainness, and emphasis on earthly pleasures, cause disgust and anxiety in Lapeteus, because he still views himself as an ideological communist. The scene depicting Reet's birthday party, which already takes place during the Thaw, is especially Fellini-like. In it, one of the guests drunkenly and jovially shouts that the monuments will soon start toppling - apparently alluding to the Staliniana.

This statement provokes lengthy Homeric laughter among guests which is filmed in close-up grotesque grimaces and causes Lapeteus to again lose his self-control. The contradiction between ideological and party communism is one of the central theoretical problems in the film and does not originate with the director Kromanov, as much as with the screenwriter Kuusberg, for whom it is important - a question that personally affected him throughout his writing career. As a dedicated ideological communist, Kuusberg the writer is often interested in party communism and its widespread moral double standard; and probably also, more broadly, in the careerism, egoism, and materialism in a society that is established on socialist ideals. He had the subject matter at hand - Kuusberg had been the secretary of the board of the Writers' Union of the Estonian SSR since 1960; from 1976 to 1983 , he was the chairman of the board; and from 1968 to 1976 the editor-in-chief of the literary journal Looming, thereby also living a kind of double life as a literary functionary and writer. Nevertheless, as a literary politician Kuusberg was considered to be quite liberal and opposed to the dogmatic party members, and did his best to protect the young Estonian writers from Endel Sõgel, the most notorious literary functionary of the 1960s (Undusk 2009). In Lapeteus's story, the prototype for Sõgel can be seen in Madis Jürven, the spiteful and dogmatic party committee secretary, who efficiently tends to party purity during the Stalinist years. As an innovation for its time, the criticism of both the Stalinist and postStalinist years based on the position of ideological communism can be sensed in the film, because, in addition to the widespread criticism of totalitarianism and the cult of personality, the modernising and hedonistically oriented Soviet modernity that followed Nikita Khrushchev's rise to power is also criticised. Although for many ideological communists, the second half of the 1950 s was a time of great hope, when it was believed that after the Stalinist interlude that went wrong, the Soviet Union would return to its revolutionary era values - in Estonia too, young intellectuals read the early writings of Marx with fervour - then as the 1960s progressed, it became clear to many that the Soviet Union was only undergoing a cosmetic makeover. Reet Lapeteus can be considered to be the composite figure representing the hedonistic Soviet modernity of the 1960s, a modern and 
self-confident young urban woman, who knows how to get by comfortably and pleasantly, by Western standards, under the conditions of socialism.

In regard to the theme of ideological versus party communism, the restaurant scene with the wartime friends that occurs at a time when the ideological communist Oskar Põdrus is in the party's disfavour deserves attention. Here the main axis of opinion is drawn between the opposite poles of Pajuviidik and Haavik. If Pajuviidik does not understand the people who are judging Põdrus, then Haavik thinks that they are professionals who know what they are doing. The screenwriter clearly sympathises with the worker Pajuviidik, who is given the most meaningful and witty lines in the dialogue. For Kuusberg, who saw himself as a third-generation mason, a certain proletarian pride and work ethic form a significant part of his public image (Palm 1986). When discussing the nature of socialism and the purpose of life with his friends at the restaurant, Haavik whispers angrily that this is not the proper place for such a discussion. Pajuviidik, who always provokes a heated desire to quibble in Haavik's cowardly and bureaucratic nature, answers by banging his hand loudly on the table, making the dishes clatter, and saying "I think this is exactly the right place because if we only talk about socialism at the podium, but otherwise think about kopecks, liquor bottles and babes with large boobs, then we will see as much of a new life as we see of our own ears." If in the film, we see Pajuviidik as a colourful personality and individual, whereas Haavik is more of a function of a certain kind of system. However, the battle between the individual and the function in the film continues and it is far from clear which one actually wins. According to Undusk, most of the communists with conviction in Kuusberg's works remain outsiders or get beaten up by life, but there are surprising nuances to the thrashings they receive (Undusk 2009). Because in a totalitarian system, the individual is meant to be invisible, as expressed by Arendt, "[f]or to destroy individuality is to destroy spontaneity, man's power to begin something new out of his own resources, something that cannot be explained on the basis of reactions to the environment and events" (Arendt [1951] 1973: 455).

Põdrus's witch trial is a good example of the pressure exerted by the collectively thinking man on the independently thinking individual. At the meeting of the presidium, Põdrus is reprimanded for writing something into his notebook, and therefore, the presidium is seemingly allowed to decide his fate. In the director's screenplay, we can find a visually eloquent description of the scene, in which the system is represented by a large hand, and the individual by a small man: "The path to the presidium table was endlessly long for Põdrus. Jürven stands up. Põdrus, standing before the table, feels small. Jürven bends over and stretches his hand out for the notebook. Jürven's large, demanding hand. The hand gets the notebook." (Figure 4) These visual accents are also apparent in the film, and generally, Põdrus's witch trial is one of the most visually powerful scenes in the film with vigorous images speaking instead of words. This scene can also be considered to be the symphonic culmination of the film. Before the notebook is handed over, we see a sea of raised hands in response to the first condemnatory resolution, and only one hand with a bracelet in response to the second exculpatory resolution. The hand with the bracelet belongs to Helvi, Lapeteus's and Põdrus's wartime friend and appears several times in the film as a symbol of something that Lapeteus has lost in life. At the meeting of the presidium, Lapeteus himself seems to be paralysed and does not raise his hand at all. (Figure 5) Immediately after the witch trial, when he meets his friend in the foyer, he does not act like Põdrus's friend or enemy but quickly makes small talk. And yet, Lapeteus's behaviour at the time starts to haunt him later, but maybe not so much because of the lost friendship, but because of the changed conjuncture - Stalinist values had 
meanwhile been replaced by post-Stalinist ones; repressions by rehabilitations; and the totalitarian regime of fear by an appeal for a softer, more humane "socialism with a human face". However, maybe the main character should be given the benefit of the doubt, because Lapeteus's feverish ravings as he lies in the hospital bed after the accident are related to the defence of his wartime friends during the Stalinist years, although a note of self-justification is also present here. According to Arendt, the great achievement of the totalitarian regimes is the corruption of the solidarity among people - for instance, by giving people chosen from among the prisoners in concentration camps the right to make administrative decisions, it was possible to effectively blur the distinction between the persecutors and the persecuted (Arendt [1951] 1973: 451-453).

The objective of total domination is to eradicate plurality and differences so that all of humankind becomes as if one individual. To achieve this, every single person must be reduced into a bundle of the most elementary reactions, into Pavlov's dogs according to Arendt ([1951] 1973: 248). Of course, Põdrus's witch trial is not only related to his notebook, but to the party - or to the spiteful Madis Jürven personally, for whom Põdrus's pedagogical methods are a thorn in the side. Põdrus does not allow the students to just memorise the classic quotes of Marxism, but insists that in the pedagogical sense it is better to have the students analyse them. Põdrus, who has been thrown out of the party, does not understand why he was cast out like a leper, because he thinks he has behaved in the most responsible way. All the ideological communists in the film condemn the rattling off of ideological slogans by the party communists. Even Pajuviidik, when he meets Lapeteus, who is coming from a birthday party, on a railway platform, says sharply, that he is talking as if he were reading from a newspaper. Talk to your old friend like a human, he says. However, slowly, the ability of homo sovieticus to maintain two separate identities and to switch smoothly from the public context to the private one starts to erode. Therefore, homo sovieticus starts talking in the language of slogans at home and in his leisure time, with his friends and family; and the latter - unless they too are homo sovietici - start to slowly estrange from them as someone unrecognisable, bewitched. After the accident, Helvi Kaartna asks her wartime friends, "Did we ever know Andres Lapeteus?" The theme song commissioned from the famous Estonian composer Eino Tamberg and recorded by the wellknown actor and singer Helgi Sallo becomes the symbol of the story of Lapeteus as an alienated career eremite and homo sovieticus that is increasingly incapable of sincerity. The song is called "Your Eyes" and its refrain adds: "... are cold, so cold, although your mouth is smiling, you are betrayed by your eyes, that you are not true."

Immediately before the accident, Lapeteus searches for understanding from Põdrus, whom he has invited for a longer visit, by saying that the cult of personality caused a kind of wave of dogmatism, which did not pass anyone by. In answer, Põdrus asks ironically whether Lapeteus asked him for a visit in order to explain the cult of personality to him. Põdrus is irritated by Lapeteus's victimism, his portrayal of himself as a casualty of Stalinism, while actually others, not the senior workers, were the ones that suffered. Põdrus demands that those who held "cushy jobs" should now account for their actions. But Lapeteus justifies himself by saying he is not afraid of being accountable; he is not indebted to anyone. By nature, Lapeteus is a conscientious official, who is motivated by the need to do what is required, which is why spontaneous human kindnesses that break the rules often make him feel uncomfortable and uncooperative. Although right after the war, Lapeteus is still a relatively atypical official, who likes to personally visit worksites and tackle jobs himself; and during their courtship, he complains to Reet that telephones are his worst enemy and that he cannot stand his work desk. But, when years later, Pajuviidik comes to complain to Lapeteus, who now holds a high position, about the 


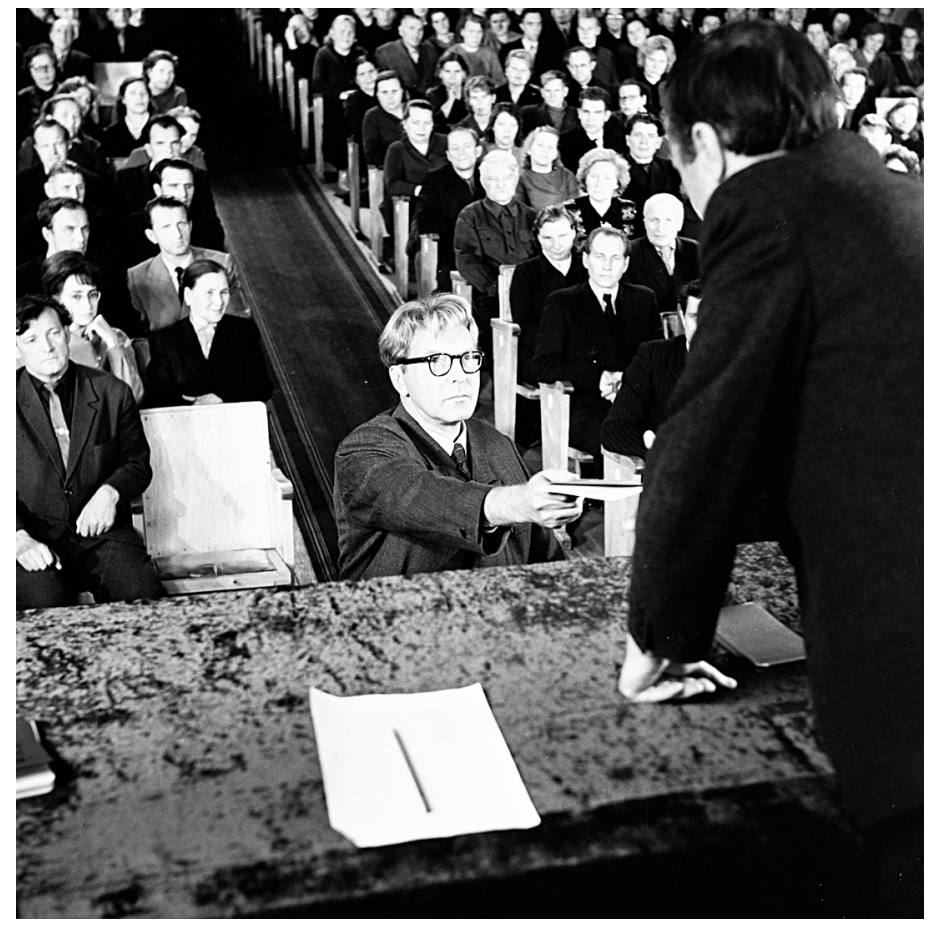

FIGURE 4. Condemned for scribbling into his notebook: Pôdrus's witch trial is one of the most visually powerful scenes in the film. Photo: Tallinnfilm / Film Archives of the National Archives of Estonia.

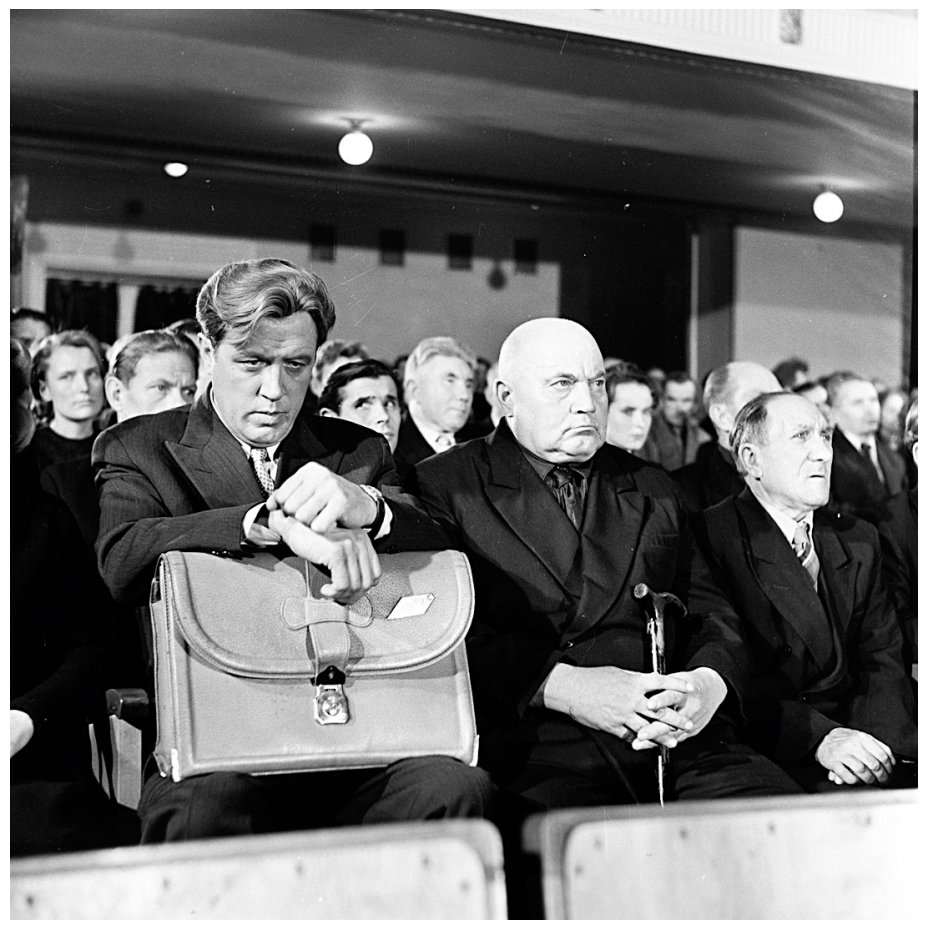

FIGURE 5. The discomfort of Lapeteus during the voting that decides the faith of his wartime friend Pódrus. Photo: Tallinnfilm / Film Archives of the National Archives of Estonia. 
negligence and petty thievery rampant at his building site, the latter does not give the complainant much hope that anything will improve. He answers his old friend automatically as if from a recording, by saying that apparently it is necessary to delve deeper into the construction problems, to examine them thoroughly, and if necessary to pose questions to the executive committee or office of the oblast committee. Lapeteus never does visit Pajuviidik's worksite, whereas at the same time, he goes from meeting to meeting and steadfastly struggles to make sure that all the reports arrive in the right place at the right time. Zinoviev describes the Soviet system as thoroughly bureaucratic and homo sovieticus as the most authentic bureaucrat: "Soviet people are trained to write reports about everything. It is an indispensable element of the Communist organisation of work. Monthly Reports, Quarterly Reports, Yearly Reports, Five-yearly Reports. [---] But we usually write reports not in order to do a summingup or extract lessons, but by virtue of certain higher, mystical considerations. For the sake of ordered formality. Therefore we put all we've got into them as a rule, so that it's practically impossible to sift the truth from invention. [---] Many years of training are required before a man becomes a qualified Reporter and begins to draft Reports of Mozartian fluency." (Zinoviev 1985: 14-16)

The European totalitarian regimes have often been described as pathological, underdeveloped forms of modernity, however, based on many of their features they should rather be seen as overdeveloped forms of modernity. Arendt was the first to discover that the processes that Max Weber had attentively observed in Prussia - secularisation, rationalisation, and bureaucratisation - were represented in an exemplary fashion in Nazi Germany. In Russian Modernity, the historian David L. Hoffmann has found that the rise of bureaucracy and state control, attempts to manage the population in a rational and productive way, scientism and expertism with faith in progress and a wish to leave tradition and religion behind, were all aspects of Soviet socialism that paralleled developments throughout Europe at the end of the 19th and 20th centuries and proved that Soviet socialism was also a product of the European Enlightenment (Hoffmann 2000: 245-246). Hoffmann even finds that some aspects of the European Enlightenment became more articulated in Marxism, but he also emphasises the need to keep states with an explicit ideological mission apart from those that were not openly ideological in order to comprehend the coming of modernity as universal trend, with unique features in each case yet to be studied comparatively (Hoffmann 2000: 245, 256). Observing the trial of the Nazi leader Adolf Eichmann in 1961, Arendt noted that the evil of the concentration camps was mainly in the fulfilment of the banal orders given by the superiors and the fact that the executioners acted like exemplary bureaucrats, who served the system impeccably without posing unnecessary questions ([1963] 2006). In Arendt's eyes, Eichmann therefore represented a totally new kind of criminal, who was law-abiding and conscientious and generally surprisingly normal, not some kind of a monster, but precisely this was frightening ([1963] 2006: 276). The Eichmann trial was covered widely by the Soviet press, but mainly as a Western performance designed to hide the terrible truth, as according the Soviets, the victims were not limited to Jews, but also included many Soviet citizens. Soviet reports more and less ignored the Holocaust itself (Cantorovich 2007: 125). The parallels between Nazism and Stalinism and the question of collective responsibility in connection with the trial were not covered, but the readers who had suffered under Stalinist repressions must have drawn these conclusions anyway. As we know, Nikita Khrushchev's de-Stalinisation policy focused on the person of Stalin and eliminating the cult of personality, as well as on reducing the size of the GULAG camp system that had been greatly expanded during the Stalinist years.

If we consider Andrei Tarkovsky's problematic film Andrei Rublev (Андрей Рублёв, Russia, 1966) and try to understand 
the success of the film What Happened to Andres Lapeteus? in that same year, we must take into account that until the Prague Spring of 1968, we are talking about the Thaw when the idea of giving socialism a more human face was still relevant, especially in the satellite countries of the Soviet Union and the relatively freer Soviet Baltic republics. However, perhaps Kromanov's film was sufficiently protected because it included the actual criticism of the cult of personality, and covered the topics of honest communists and the correct party line. In the official permits sent from Moscow during the production of the film, the same instructions were again and again repeated: "This film must place the greatest focus on the truthful depiction of the party line in post-war Estonia and demonstrate the activism of the Soviet people, who, despite all the mistakes of the cult of personality, worked successfully and lived together as a united people, as one state." ${ }^{8}$ After the premiere of the film for the participants and officials, Lembit Remmelgas, the chief editor at Tallinnfilm, summarised the discussions about the film, which, in addition to the unanimous praise, tended to revolve around the question of whether the central theme of the film was the cult of personality or not, with the following statement: "I have said a dozen times that in this novel I see the topic of the cult of personality presented in an original way and I am opposed to anything that raises new questions about this topic, and provokes sorrow, melancholy, and tears. I believe that this is a work that, for the first time in the history of Soviet literature, approaches this topic, the difficulties of the period, the errors of the period, the objective content of the period from a position of responsibility, and this is the value of the work. It does not approach the cult of personality from the aspect of prisons and jails, but rather from the aspect of people's conscience and reason." For his time, Remmelgas approached the topic of the cult of personality bravely and exceptionally, by dealing with totalitarianism from the viewpoint of Arendt-like collective responsibility and the bureaucratic fulfilment of orders. Thus, What Happened to Andres Lapeteus? can be viewed as a kind of trial held for homo sovieticus, the recurring thread of which is the abstract remorse felt by the ambitious official Lapeteus before his wartime friends, which he does not totally comprehend, but which constantly accompanies him and intensifies after the accident.

Although Khrushchev only managed to remain at the head of the Soviet Union until 1964, he was able to inject the requirement for contemporaneity into the official canon of art along with calling for art to be more true-to-life (Hruštšov 1957). What Happened to Andres Lapeteus? deals excellently with the contemporary problems of contemporary people, if we consider the 1960s topics that are covered in the film like the new Post-Stalinist Soviet nomenklatura, a modernising urban lifestyle, as well as fashionable careerism and the social and sexual capital that is associated with it. In a way, a fragmented journalistic style also became fashionable during the Thaw, because lighter genres were now used in the arts to counterweight the high Stalinist style. In painting, thematic compositions depicting ceremonial moments were replaced by everyday subjects, and a kind of clumsiness and sketchiness in the finishing and a freer style of painting became fashionable. In retrospect, the Russian art historian Aleksandr Kamenski connects the "severe style" that was popular in the painting of the Thaw era to the psychological tuning fork of the era, which was characterised, as a post-war after-effect, by new optimism and intolerance for the sugary lies of the Stalinist socialist realism years, and a passionate thirst for the truth, which was expressed in art by an aspiration for "masculine simplicity" and the "severe truth" (Каменский 1989: 185). Similar changes took place in the cinema, to which Alexander Prokhorov, the researcher of the Thaw-era Soviet cinema, has called typical anti-monumentalism and a thirsting for individual self-expression, which would allow the revolutionary spirit 
to be revived (Prokhorov 2001: 8). According to Näripea, based on its formal techniques, What Happened to Andres Lapeteus? can be viewed against the background of the Soviet new wave cinema of the 1960s, in which the fragmentary nature of the narratives, ambivalence, and artistic searching formed the basis for a fresh visualisation of stories (2006: 57). At the Tallinnfilm Art Council, director Kromanov defends his unusual collage-like editing, which according to some critics disconcerts the viewers, as follows: "An abstract of the novel is the only way to go. To violate this and start relating the effects in order would impoverish the investigation into who Lapeteus was, what happened to him and why it happened in this way." The story of the fatal adventures of an individual who gets caught in the gears of Soviet modernity is also told in Soviet cinema by Mikhail Romm, director of The Nine Days of One Year (Девять дней одного года, Russia, 1961), a film about a young Soviet nuclear physicist who gets carried away by his scientific work, receives deadly doses of radiation, and grows ever greater alienation from his private self and life.

\section{CONCLUSION}

Paul Kuusberg and Grigori Kromanov's joint work What Happened to Andres Lapeteus? tells an engrossing story about a lost Soviet generation, who went to war directly from the classroom and could not start searching for their place in life until the war ended, therefore grew up during the Stalinist years and achieved their aspirations during the Thaw. Parallel in time to the beatnik generation in the USA, the post-war Soviet Union does not enable the younger generation to publicly manifest their war experiences or the resignation and sense of protest that it caused. When returning from the war they immediately get caught in the gears of the harsh Stalinist regime and the nascent self of this generation never really becomes fully developed. What Happened to Andres Lapeteus? observes the development of postwar homo sovieticus, witnessing his growing into upper-class Soviet functionary, but as time passes, also his becoming dysfunctional in the Soviet system. Many East European thinkers have defined the concept of homo sovieticus as an adaptive transitional type, which appears in Soviet society during late socialism and represents certain official ritualistic behaviour that maintains the symbolic legitimacy of power. If Aleksander Zinoviev, whose writing is based on Russian material, treats homo sovieticus mainly as a perfect conformist and skilful opportunist, then Jozef Tischner, who bases his conclusions on the Polish experience, also observes overdeveloped fatalism and the belief that it is impossible to influence or change the socialist reality from the human level.Václav Havel, one of the most influential Czech intellectuals, has explained the individual's role, which seems unimportant at first glance, but is still a decisive factor in keeping the totalitarian clockwork running, as follows: "Individuals need not believe all these mystifications, but they must behave as though they did, or they must at least tolerate them in silence, or get along well with those who work with them. For this reason, however, they must live within a lie. They need not accept the lie. It is enough for them to have accepted their life with it and in it. For by this very fact, individuals confirm the system, fulfil the system, make the system, are the system." (Havel 1978) Several Western critics of modernity have found that the totalitarian regimes of 20th-century Europe are nothing more than escalated manifestations, or overdeveloped forms, of post-Enlightenment modernity oriented toward secularism, rationalisation, and bureaucratisation. Arendt has even found that the totalitarian regimes represented the best oiled machines of modernity, the smooth running of which is ensured by the individual who has become invisible, in whom the things that are hardest to destroy have been destroyed - individuality and spontaneity, the power to begin something new out of one's own resources, something that cannot be explained on the basis of reactions to the environment and events. 
REFERENCES

Arendt, Hannah [1951] 1973. The Origins of Totalitarianism. New edition. New York: Harcourt Brace Jovanovich. Arendt, Hannah [1963] 2006. Eichmann in Jerusalem: A Report on the Banality of Evil. New York: Penguin Books.

Cantorovich, Nati 2007. 'Soviet Reactions to the

Eichmann Trial: A Preliminary Investigation 1960-1965'

- Yad Vashem Studies, 35, 2, 103-141.

Havel, Václav 1978. The Power of the Powerless.

http://vaclavhavel.cz/showtrans.

php?cat=clanky\&val=72_aj_clanky.html\&typ $=H T M L$

(4 June 2014).

Hoffmann, David L. 2000. 'European Modernity and

Soviet Socialism: - David L. Hoffmann, Yanni Kotsonis (eds.), Russian Modernity: Politics, Knowledge, Practices. London: Macmillan Press; New York: St. Martin's Press, 245-260.

Hruštšov, Nikita 1957. 'Kirjandus ja kunst olgu tihedalt seotud rahva eluga'. - Rahva Hääl, 30 August.

Каменский, Александр 1989. Романтический монтаж. Москва: Советский художник.

Koppel, Margit-Mariann 1998. 'KGB hammasrataste vahel - Heino Mandri'. - Teater. Muusika. Kino, 10, 43-44.

Kuusberg, Paul 1966. Andres Lapeteuse juhtum. Tallinn: Eesti Raamat.

Langemets, Andres 2010. 'Üks suur ja mäda põlvkond'. - KesKus, 3.

Lõhmus, Jaak; Vaher, Märten 2012. Kaadris: "Mis

juhtus Andres Lapeteusega?". http://arhiiv.err.ee/vaata/ kaadris-mis-juhtus-andres-lapeteusega (20 October 2014).

Marody, Mira 2010. 'Homo Sovieticus and the Change of Values: The Case of Poland'. - Landmark 1989: Central and Eastern European Societies Twenty Years After the System Change. Berlin, Münster: Lit, 80-90.

Miłosz, Czestaw 1999. Vangistatud mõistus. Trans. Hendrik Lindepuu. Tallinn: Loomingu Raamatukogu. Nirk, Endel 1963. 'Mis juhtus Andres Lapeteusega?' Keel ja Kirjandus, 12, 705-712.

Näripea, Eva 2006. 'Film, ruum ja narratiiv: 'Mis juhtus Andres Lapeteusega?' ning 'Viini postmark” / 'Film, Space and Narrative: 'What Happened to Andres Lapeteus?' and 'The Postage-Stamp of Vienna”. Kunstiteaduslikke Uurimusi / Studies on Art and Architecture, 15, 4, 55-76.

Palm, Vilja 1986. Ōhtutund kirjanikuga: Paul Kuusberg. http://arhiiv.err.ee/vaata/ohtutund-kirjanikugapaul-kuusberg (20 October 2014).

Prokhorov, Alexander 2001. 'The Unknown New Wave: Soviet Cinema of the Sixties'. - Alexander Prokhorov (ed.), Springtime for Soviet Cinema: Re/Viewing the 1960s. Pittsburgh, 7-28. http://www. rusfilm.pitt.edu/ booklets/Thaw.pdf (8 June 2014).

Rahvusarhiiv. ERA, f R-1707, n 1, s 963. Kunstilise filmi "Mis juhtus Andres Lapeteusega" toimik. 1966.

Tischner, Józef 2005. Etyka solidarności oraz Homo sovieticus. Krakow: Znak.

Tyszka, Krzysztof 2009. “Homo Sovieticus'Two Decades Later'. - Polish Sociological Review, 168, 507-522.

Undusk, Jaan 2009. 'Eesti lugu: Paul Kuusberg 'Andres Lapeteuse juhtum". - Eesti Päevaleht, 12 June.

Зиновьев, Александр 1981. Коммунизм как реальность. Lausanne: L'Âge d'Homme.

Зиновьев, Александр 1983. Нашей юности полёт.

Lausanne: L'Âge d'Homme.

Zinoviev, Alexander 1985. Homo Sovieticus. Boston, New York: The Atlantic Monthly Press.

Zubkova, Jelena 2009. Baltimaad ja Kreml 1940-1953.

Trans. Margus Leemets. Tallinn: Varrak. 